\title{
Measuring And Explaining Turkey's Competitiveness in Services Using Balassa Index and Diamond Model
}

\author{
Abdulkadir GÜMÜŞ \\ Sakarya University \\ Faculty of Management, Sakarya, Turkey \\ agumus@sakarya.edu.tr
}

\author{
Mahmut HIZIROĞLU \\ Sakarya University \\ Faculty of Management, Sakarya, Turkey \\ hiziroglu@sakarya.edu.tr
}

\begin{abstract}
This study aims investigating the competitiveness of the selected services in Turkey in comparison with the European Union (EU) and the selected EU countries. The main argument of conducting this research stems from the fact that there is a lack of complementary research integrating qualitative and quantitative methodologies in gaining deeper understanding on the competitiveness of the nations in services in the related literature. In order to contribute to the current body of knowledge on that matter, Porter's Diamond Model and three different revealed comparative advantage indices have been employed in a combined way within the scope of this study. The findings show that strong comparative advantages exist for Turkey in construction, tourism and transportation sectors. Although Turkish financial and insurance and communication and computer-information sectors appear to be weak compared to EU, there is a substantial potential for improvement. The policy decision makers in Turkey and in Europe's selected countries can utilize the findings and recommendations of the study for projection of the investigated sectors.
\end{abstract}

Key Words: Revealed comparative advantage, diamond model, service competitiveness, trade in services, competitive advantage

\section{Introduction}

International competitiveness is a prominence phenomenon to which scholars in wide range of scientific fields as well as policymakers have turned their attention. Giving the fact that services as a trade instrument have become rather crucial and critical in the growth of economies in many nations, the research associated with measuring the competiveness in services are limited. In particular, assessing competitiveness of different nations has become of great importance as there are only few empirical researches exist in the current body of the literature. One of the main reasons for this is the fact that the value of trade in services is underestimated and the comparable data on services are not comprehensive and fully available. Therefore, this study aims to fill this gap in the related literature to some extent. To accomplish that, the competitiveness of the selected services in Turkey in comparison with the EU and 
the selected EU countries is investigated in this study. To contribute the current literature within this context, the aim of this study is to investigate the competitiveness of the selected services the way in which qualitative and quantitative examinations are being integrated in gaining a deeper understanding of what makes Turkish service sectors competitive against EU countries. At first, three Revealed Comparative Advantage (RCA) indicators were utilized in order to measure the comparative advantages. Then, Porter's Diamond Model (1990) was adopted in pursue of an explanation for the underlying reasons behind the competitiveness obtained by RCA indicators.

The term revealed comparative advantage was first proposed by Balassa (1965) and it has been widely accepted by the corresponding authorities as an indicator for international competitiveness. The fundamental idea behind RCA is the law of comparative advantage which takes into account the relative trade (import/export) of a country for a good or group of goods (Hisanaga, 2007). The existing literature provides sufficient discussions and proves on the applicability of RCA in international trade in services (Igawa, 1997,Langhammer, 2004, Hisanaga, 2008). However, RCA is far from providing the underlying causes of competitiveness of a nation in a particular industry. Since Balassa index is largely quantitative and do not fully tap into the complex and dynamic nature of competitiveness and its determinants, employing both qualitative and quantitative analyses would be better able to provide this information and offer new insights into service competitiveness.

To answer the question of why a nation achieves international success in a particular industry, Porter (1990) proposes the Diamond Model of country competitiveness. The Porter (1990) identifies four country attributes (factors) and two external variables or outer factors that help understand the underlying conditions for determining the competitive advantage of a nation. These attributes are: factor conditions, demand conditions, related and supporting industries, firm strategy and company structure, the roles of the government and chance (the last two are outer factors). Porter's four determinants and two outside forces interact in the "diamond" of competitive advantage in which the nature of a country's international competitiveness depends upon the type and the quality of these interactions. Although pros and cons of Diamond Model are still debated in the literature, it is still considered to be useful to understand the drivers of the level of competitiveness at a given sector.

\section{Recent Studies on Competitiveness in Services}

There is a burgeoning literature on international trade in services. On one hand, some of these work provide discussions on the role of trade in services in economic growth (e.g. Hoekman and Mattoo, 2008; Maurizio, 2006; Nielson and Taglioni 2004). On the other hand, the other strand of literature discuss how cross border trading can be realized and how to measure the comparative advantage of countries in a given service sector (Bensidoun and Unal-Kesenci, 2008; Hufbauer and Stephenson, 2007; Nordas, 2008). Associated with the first group of studies, it is important to refer to the studies conducted by WTO and OECD most of which are exploratory and conceptual. For example, in a study conducted by Nielson and Taglioni (2004), concrete examples of exports of services by developing countries and quantitative studies on the gains from liberalization were identified. They argue that while developed countries dominate services trade overall, developing countries seem to be particularly successful in certain 
labour-intensive sectors, such as port and shipping services, audio-visual services, construction services and health services. Moreover, there is also growing body of literature published by OECD that explains how service sub-sectors contribute to international competitiveness. For instance, Korinek and Sourdin (2011) investigated the role of trade logistics play in the volume and value of international trade and the extent to which poor quality logistics constitute a barrier to trade. Likewise, Ju and Wei (20011) discussed how the quality of a financial system and the underlying factor endowment jointly determine patterns of production and trade.

The studies mentioned above are mostly conceptual and explanatory. There are also a few empirical works regarding the competitiveness of services. The review has been done focusing only on the articles that include Turkey as a comparative object. All of the previous studies took into account the classification accepted by IMF, BPM. Amongst the work being conducted using RCA indices, Seyoum (2007) analysed the competitiveness of business, financial, transport, and travel services in developing countries in comparison with the World. The results showed that important comparative advantages exist for many developing countries in transport, and travel services, and there is substantial room for improvement in financial and business services. According to his findings, Turkey showed revealed comparative advantages in business, travel, and transport services. Hisanaga (2007) investigated the comparative structure of US international trade in services compared to the World, UK. France, Greece, Turkey, Germany, Japan, Ireland, Russia, China, P.R. Mainland. The investigation results indicated that U.S. consistently had a comparative advantage in knowledge-based services. Kuznar (2007) examined the international trade in services, particularly the position of developing countries. His results indicated that low and middle income economies are competitive in services trade, especially in labour intensive activities. The study conducted by Mohammadi and Yaghoubi (2007) focused on developing countries to determine which countries possibly have a comparative advantage in the export of e-services and why. They analysed competitiveness in computer and information, financial, transportation, and travel services. Their results highlighted that many developing countries have revealed comparative advantages in travel/tourism and transport services. Fourie and Fintel (2007) provided a snapshot of the 2005 country rankings of service exporters. They included 147 countries in their analysis by focusing on ten sectors.

According to their results, Turkey has a strong comparative advantage in travel, construction, personal, cultural, and recreational service export. 
A. Gümüş - M. Hızıroğlu 7/2 (2015) 195-213

Table 1 Empirical studies on competitiveness in services

\begin{tabular}{|c|c|c|c|c|c|c|}
\hline $\begin{array}{l}\text { HISANAGA } \\
(\underline{2007)}\end{array}$ & $\begin{array}{l}\text { U.S. } \\
\text { 1989-2003 }\end{array}$ & 35 Countries & $\begin{array}{l}\text { BPM / } \\
\text { Transportation, } \\
\text { communication, } \\
\text { financial, royalties and } \\
\text { license fees, personal, } \\
\text { cultural, and } \\
\text { recreational, goods, } \\
\text { computer and } \\
\text { information, other } \\
\text { business }\end{array}$ & $\begin{array}{l}\text { Investigation of } \\
\text { the comparative } \\
\text { structure of U.S. } \\
\text { international } \\
\text { trade in services }\end{array}$ & RCA & $\begin{array}{l}\text { U.S. } \\
\text { consistently } \\
\text { had a } \\
\text { comparative } \\
\text { advantage in } \\
\text { knowledge- } \\
\text { based services. } \\
\text { Especially in } \\
\text { the category of } \\
\text { Royalties and } \\
\text { License Fees } \\
\text { consistently } \\
\text { maintains a } \\
\text { higher } \\
\text { comparative } \\
\text { advantage. }\end{array}$ \\
\hline $\begin{array}{l}\text { MUHAMMADI } \\
\text { AND } \\
\text { YAGHOUBI } \\
(\underline{2008)}\end{array}$ & $\begin{array}{l}\text { Developing } \\
\text { countries } \\
1998-2004\end{array}$ & $\begin{array}{l}\text { Developing } \\
\text { countries }\end{array}$ & $\begin{array}{l}\text { BPM / Computer and } \\
\text { information, financial, } \\
\text { transportation, travel } \\
\text { services }\end{array}$ & $\begin{array}{l}\text { Which countries } \\
\text { have a } \\
\text { comparative } \\
\text { advantage in the } \\
\text { export of e- } \\
\text { services and } \\
\text { why? }\end{array}$ & $\begin{array}{l}\text { Three } \\
\text { indices of } \\
\text { RCA }\end{array}$ & $\begin{array}{l}\text { Many } \\
\text { developing } \\
\text { countries have } \\
\text { revealed } \\
\text { comparative } \\
\text { advantages in } \\
\text { travel/tourism } \\
\text { and transport } \\
\text { services. }\end{array}$ \\
\hline $\begin{array}{l}\text { EUROSTAT } \\
(\underline{2008)}\end{array}$ & $\begin{array}{l}\text { EU, } \\
\text { Mediterranean } \\
\text { Partner } \\
\text { Countries } \\
\text { 2001-2006 }\end{array}$ & EU, MPCs & $\begin{array}{l}\text { BPM / } \\
\text { Services in general, } \\
\text { esp. transport and } \\
\text { travel }\end{array}$ & $\begin{array}{l}\text { Statistics of trade } \\
\text { in services } \\
\text { between the } \\
\text { European Union } \\
\text { and the } \\
\text { Mediterranean } \\
\text { Partner Countries }\end{array}$ & $\begin{array}{l}\text { Descriptive } \\
\text { statistics }\end{array}$ & $\begin{array}{l}\text { Trade in } \\
\text { services } \\
\text { between EU } \\
\text { and MPCs } \\
\text { increasing } \\
\text { gradually }\end{array}$ \\
\hline $\begin{array}{l}\text { FOURIE AND } \\
\text { FINTEL }(\underline{2009})\end{array}$ & $\begin{array}{l}2005 \text { country } \\
\text { rankings } \\
1980-2006\end{array}$ & 147 Countries & $\begin{array}{l}\text { BPM /Transport, } \\
\text { travel, } \\
\text { communications, } \\
\text { insurance, financial } \\
\text { services, computer and } \\
\text { information, royalties } \\
\text { other business } \\
\text { services, personal, } \\
\text { cultural and } \\
\text { recreational services }\end{array}$ & & $\begin{array}{l}\text { Three } \\
\text { indices of } \\
\text { RCA }\end{array}$ & $\begin{array}{l}\text { Turkey has } \\
\text { strong } \\
\text { comparative } \\
\text { advantage in } \\
\text { travel, } \\
\text { construction, } \\
\text { personal, } \\
\text { cultural, and } \\
\text { recreational } \\
\text { service exports }\end{array}$ \\
\hline
\end{tabular}


Although it is possible to see some research on the competitiveness of Turkey in service sectors, the current literature can be considered as limited in terms of the details of the analyses being done in them and the implications of these researches could provide for policy makers in Turkey. Also, the latest research in this context may not be considered up to date with regards to the data they contain. Therefore, there is a need for a recent study, which embodies a detailed examination on measuring the competitiveness of Turkey in comparison with EU to obtain more practical results with managerial implications. The next section provides detailed information regarding the method being followed within the scope of this study.

\section{Methodology}

Within the scope of this study, both an econometric model and a qualitative method were used as a complementary approach in order to understand the competitiveness of Turkey in service sectors compared to the selected EU countries. Firstly, three Revealed Comparative Advantage (RCA) indicators were utilized in order to measure the comparative advantages. In order to understand the underlying reasons of the level of competitiveness based on RCA indicators Porter's Diamond Model (1990) was adopted to evaluate national competitiveness.

Although different versions of RCA were studied in the related literature, three basic comparative advantage indices were utilized within the scope of this study. The basic ideas behind these indices are as follows:

The first one is RCA index which calculates the comparative advantage based on export figures. Through the usage of RCA index, one can determine whether a nation has been in a process of increasing the goods of which it has the trade potential or not and if the current number of goods that have been exported competitively in a nation has been static. The basic modelling of RCA index is presented below. According to this formula, the RCA index of nation $i$ for good (or group of goods) $j$ is measured as the ratio of total export share of that good (or group of goods) for nation $i$ and the export share of the nation (or group of nations) that is under comparison. Here, while $X_{i j}$ and $X_{w j}$ indicates export of good $\mathrm{j}$ for nation $\mathrm{i}$ and the other nations (or group of nations), respectively, $X_{i t}$ and $X_{w t}$ refer to the corresponding total export figures. If the calculated ratio is greater than 1 then this could be interpreted as a high revealed comparative advantage, on the other hand the ratio is below 1 designates a low comparative advantage.

$$
R C A_{i j}=\left(X_{i j} / X_{i t}\right) /\left(X_{w j} / X_{w t}\right)
$$

The second index is called Relative Import Advantage (RMA) and it can be calculated through interpreting and formulating the RCA index with corresponding import values. In other words, changing the export values $(\mathrm{X})$ to import values $(\mathrm{M})$ as expressed in the formula below yields RMA values. According to this formula, a nation has competitive advantage (disadvantage) for import of that good or group of goods should a value of index smaller (bigger) than 1 is obtained.

$$
R M A_{i j}=\left(M_{i j} / M_{i t}\right) /\left(M_{w j} / M_{w t}\right)
$$


Third index is Relative Trade Advantage Index (RTA) which is formulated by the subtraction of relative export (RCA) and import (RMA) advantage indexes as shown below:

$$
R T A_{i j}=R C A_{i j}-R M A_{i j}
$$

For the formulations presented above, it should be noted that goods or group of goods can be considered as service or group of services when the necessary operationalization is tailored to service sectors. In this study, service sector is classified based on Extended Balance of Payments Services (EBOPS). Table below shows the sector group numbers for related sectors that were taken into account for analysis. The indices mentioned above were used to compare Turkey's competitive potential in the service sectors shown in table below with EU161, which is the 16 countries of EU, and leading countries in services sector which are Germany (DE), France (FR), Italy (ITA), United Kingdom (UK), Belgium (BE), Netherlands (NL) and Spain (ES). To evaluate the competitiveness of the service sectors the import and the export figures from 2000 to 2011 of these counties were acquired. The data was obtained from World Bank and OECD International Trade databases. This study will utilize BPM method for empirical analyses.

This classification has the following service categories: transportation, travel, construction, insurance, computer and information, royalties and license fees, personal cultural and recreational, government (not included elsewhere) and other business services.

Table 2.The service sectors investigated

\begin{tabular}{|l|l|}
\hline SECTOR NAME & BPM SECTORIAL CODE \\
\hline Transportation & 205 \\
\hline Tourism (Travel and Cultural-Recreational & 236,287 \\
\hline Financial and Insurance & 253,260 \\
\hline Communication and Computer-Information & 245,262 \\
\hline Construction & 249 \\
\hline
\end{tabular}

Secondly, Diamond Model (Porter, 1990) is employed to evaluate the findings from RCA analyses. Diamond Model analyses international competitiveness in order to identify the determinants of competitiveness advantages in a systematic way. Porter (1990) claimed that nations may establish their advanced factors such as qualified labour force, strong technology, knowledge and culture and pointed that this can only be achieved under specific conditions. The model consists of four determinants: The first category of determinants is factor conditions which include human, capital and physical resources as well as the physical and knowledge infrastructure of a country. The second factor is demand conditions such as the structure of demand in domestic market; the size and growth rate of the demand; and the processes through which domestic demand is internationalized. The third factor refers to related and supporting industries. This

\footnotetext{
${ }^{1}$ EU16 Countries: Austria, Belgium, Cyprus, Finland, France, Germany, Greece, Ireland, Italy, Luxemburg, Malta, Netherlands, Portugal, Slovak Republic, Slovenia, Spain.
} 
entails the clustering of suppliers, knowledge-input institutions and end-users in close proximity which stimulate innovation and competitiveness. The fourth factor is firm strategy, structure and rivalry. This includes the ways in which firms are managed and choose to compete as well as the ways national and firm cultures shape education and the pool of employer talent.

Due to the fact that Diamond Model is a qualitative by nature, data sources comprise primary and secondary data sources. In order to operationalize Diamond Model, semi-structured in-depth interview method was used as data collection technique to acquire primary data. The questions have been prepared in the light of the main and sub variables of the Diamond Model. In-depth interview method was conducted on 37 participants by asking questions to the managers of enterprises operating in the selected sectors, managers and members of the associated non-governmental organizations. Secondary data source include the sectorial reports and books, databases, and journals. The aim of conducting various data collection methods is to acquire adequate information by focusing on different highlights of diverse data sources.

\section{Empirical Findings}

The comparative advantage indices of Turkey in comparison with the selected European countries and group of EU16 countries are shown in Table 3. However, the figures in the table are the average values for the period of 2000-2011. Since the aim was to investigate competiveness of Turkey against the main EU countries in certain service sectors, the analyses were done by investigating each comparative advantage index separately and looking at them simultaneously. Also, for the period being investigated the fluctuations in the status of competitive advantages/disadvantages were also examined. The most significant findings of the RCA analyses and the corresponding complementary Diamond model results were provided in the following sub-sections:

Table 3 Average values of the comparative advantage indices for Turkey (2000-2011

\begin{tabular}{|c|c|c|c|c|c|c|c|c|c|c|c|c|c|c|c|c|c|c|}
\hline \multirow{3}{*}{$\begin{array}{l}\text { COMPARATIVE } \\
\text { BASE/SERVICE } \\
\text { SECTOR }\end{array}$} & \multirow{2}{*}{\multicolumn{3}{|c|}{ TRANSPORTATION }} & \multicolumn{6}{|c|}{ TOURISM } & \multirow{2}{*}{\multicolumn{3}{|c|}{$\begin{array}{l}\text { FINANCIAL AND } \\
\text { INSURANCE }\end{array}$}} & \multirow{2}{*}{\multicolumn{3}{|c|}{$\begin{array}{l}\text { COMMUNICATION } \\
\text { AND COMPUTER- } \\
\text { INFORMATION }\end{array}$}} & \multirow{2}{*}{\multicolumn{3}{|c|}{ CONSTRUCTION }} \\
\hline & & & & \multicolumn{3}{|c|}{ Travel } & \multicolumn{3}{|c|}{$\begin{array}{c}\text { Cultural- Recreational } \\
\text { Activities }\end{array}$} & & & & & & & & & \\
\hline & RCA & RMA & RTA & RCA & RMA & RTA & RCA & RMA & RTA & RCA & RMA & RTA & RCA & RMA & RTA & RCA & RMA & RTA \\
\hline EU16 & 0,803 & 1,564 & $-0,761$ & 2,332 & 0,894 & 1,438 & N/A & N/A & N/A & 0,49 & 2,878 & 2,389 & N/A & N/A & N/A & $\mathrm{N} / \mathrm{A}$ & N/A & N/A \\
\hline GERMANY & 0,772 & 1,845 & $-1,073$ & 3,411 & 0,702 & 2,709 & 12,603 & 2,024 & 10,578 & 0,418 & 4,313 & 3,894 & 0,387 & 0,137 & 0,402 & 0,88 & 0,137 & 0,744 \\
\hline FRANCE & 0,775 & 1,310 & $-0,535$ & 1,673 & 0,87 & 0,803 & 3,817 & 1,464 & 2,353 & 1,318 & 3,777 & 2,459 & 0,306 & 0,228 & 0,393 & 1,333 & 0,228 & 1,105 \\
\hline UK & 1,239 & 1,707 & $-0,468$ & 4,193 & 0,686 & 3,507 & 3,965 & 4,084 & $-0,118$ & 0,107 & 2,186 & $-2,08$ & 0,308 & 3,133 & $-0,61$ & 15,706 & 3,133 & 12,573 \\
\hline SPAIN & 1,084 & 1,414 & $-0,33$ & 1,233 & 1,264 & $-0,03$ & 6,334 & 1,177 & 5,158 & 0,722 & 2,505 & 1,783 & 0,184 & 0,521 & 0,322 & 2,964 & 0,521 & 2,443 \\
\hline BELGİUM & 0,714 & 1,624 & $-0,909$ & 3,782 & 0,933 & 2,849 & 6,763 & 1,639 & 5,124 & 0,357 & 1,728 & 1,371 & 0,286 & 0,179 & $-0,33$ & 1,117 & 0,179 & 0,938 \\
\hline NETHERLANDS & 0,606 & 1,684 & $-1,078$ & 4,544 & 1,083 & 3,461 & 6,673 & 3,955 & 2,718 & 1,477 & 4,625 & 3,148 & 0,598 & 0,255 & 0,143 & 1,128 & 0,255 & 0,873 \\
\hline ITALY & 1,142 & 1,664 & $-0,522$ & 1,498 & 0,991 & 0,507 & 7,339 & 2,447 & 4,892 & 0,783 & 3,631 & 2,848 & 0,325 & 0,168 & 0,167 & 1,661 & 0,168 & 1,494 \\
\hline
\end{tabular}




\subsection{The Position of Turkey's Transportation Sector in the Context of both RCA and Porter's Diamond Model}

RCA findings: With regards to the comparative advantage based on export values, Turkey has competitive advantage over Italy, United Kingdom, and Spain in contrary to the other countries and the EU16. However, there seems to be no comparative advantage exists for Turkey based on import and relative trade indices. When all three indices were taken into account simultaneously, Turkey does not possess any advantage over any European country. Having analysed the initial (2000) and the final (2011) values of RCA indices, Turkey has changed its competitiveness status from being disadvantageous to advantageous in comparison with Italy, United Kingdom, and Spain. But as for RMA index is concerned, Turkey has lost its comparative advantage against Spain.

Factor Conditions: There are some advantages and disadvantages of Turkey's transportation sector in terms of factor conditions which affect the level of competitiveness. One of the most important advantages is that Turkey has a relative cheap workforce compared to EU countries. The second advantage of Turkey is geographic location. Turkey is at the crossroads of Europe, the Balkans, Black Sea, Caucasus, Central Asia, North Africa and the Middle East. Another advantage is that the enterprises operating in transportation sector have a strong merchant fleet. However, the disadvantages of sector seem much more than advantages. Some of them are high staff turnover rate, lack of skilled and qualified staff, lack of operators, inadequate transport sub-system such as rail, marine and pipeline, relatively out dated technological basis. Enterprises also suffer from insufficient financial resources for capital investment. Insufficient transportation infrastructure and old vehicles are another problem of the sector. Additionally and perhaps most importantly, the cost of petroleum and oil products is higher than most European countries.

Demand Conditions: The growth rate of logistic sector in Turkey is more than $20 \%$ per year, while this is about $10 \%$ in the World (Ministry of Industry and Trade, 2010). According to IATA, Turkey is one of the five most potential countries which will increase the growth rate of air cargo transportation within next five years (Ministry of Transport and Communication, 2011). Additionally, increasing Turkey's foreign trade in manufacturing industries provides a positive contribution to increase in demand in this sector and; accordingly, there is high demand for both rail and road freight transportation. However, firms operating in other industries do not outsource the need of their transportation activities. The most prominent barrier in development of this sector is that passenger and freight transportations are predominantly carried out via highways.

Firm Strategy and Rivalry: Due to the fact that transportation is relatively an emergent sector in Turkey and mostly consists of institutionalized domestic small and medium enterprises (except airline passenger transportation); they do not have sufficient managerial and organizational requirements for competing with multi-national companies. Yet, the presence of multi-national companies can be seen positively in terms of transferring sectorial know-how to the domestic players. In recent years, there is an increase in the number of multi-national companies operates in logistics sector. This increase also led to an increase in joint ventures and mergers. The most important 
problem in terms of competition is that there are a large number of unregistered vehicles and underground companies engaged in transportation sector.

Related and Supportive Industries: Turkey has strong ship building, freight vehicles and bus manufacturing industries and that supports the transportation sector by providing relatively low cost vehicles to the enterprises. There is also an increase in the volume of manufacturing in other industries such as industrial raw materials, the automotive industry, household appliances and machine tool parts which triggers the growth of transactions in this sector due to their export needs. Increasing domestic and overseas business trips and touristic travels also supports the sector. However, lack of specialized ports for a specific type of freight, and lack of link between ports and railroads reduce the efficiency of transportation sector in Turkey. Additionally; as for the subsectors such as subway and light rail system projects are concerned, Turkey is highly dependent on the imports.

\subsection{The Position of Turkey's Tourism Sector in the Context of both RCA and Porter's Diamond Model}

RCA findings: Travel subsector seems to be quite lucrative for Turkey as its revealed comparative advantages against all of the European countries were found to be greater than one. This competitive advantage is also valid for import figures except when the comparison is made to Netherlands and Spain. In cultural-recreational activities, although a similar conclusion can be made for Turkey's comparative advantage based on export values its competitive position appears to be disadvantageous when the import figures are considered. When the change in these values are observed in travel subsector, there is a positive advantage trend compared to Italy (based on export) and Spain (based on import and relative trade). As far as cultural-recreational activities are concerned, Turkey's competiveness also shows a positive tendency in comparison with United Kingdom (relative trade), France, Spain, Belgium, Italy (import) and Netherlands (both import and relative trade).

Factor Conditions: Due to the fact that Turkey has advantageous factor conditions such as having a wide range of natural and cultural diversity and many important destinations ( 9 of them are regarded as World Cultural Heritages) tourism industry has been one of the most important drivers behind Turkey's economic development over recent decades. However, having a weak infrastructure system and lacking of certification system to guarantee the quality of services are prominent disadvantageous of the sector. Additionally, due to circumstances such as economic crises and terrorism beyond Turkey's control, Turkey's tourism sector has been under threat in terms of economic ups and downs.

Demand Conditions: Turkey has a great potential to attract tourists from very different regions of the World. It also has the potential to become a year-round destination. Turkey took the 8th place in terms of the number of arrivals in the World based on WTO data in 2009. However, international tourist arrivals and tourism receipts have been growing rapidly over the years. The growth in Turkish tourism sector has been faster than that of the globe. The share of Turkish tourist arrivals in the World has increased from around 1\% in 1990 to approximately 3\% in 2011. The share of tourism receipts in the global tourism GDP, likewise, has increased from $1.2 \%$ in 1990 to around $2.5 \%$ in 2010 (WTO, 2010). However, due to the fact that the tourism industry is shaped by certain type of instruments activities, in particular sea, sun and sand, the 
tourism demand in Turkey is not sophisticated and mainly depends on low and middle class travellers.

Firm Strategy and Rivalry: Tour operators in Turkey put efforts in establishing international connections. As a result of this, Turkish hotels and destinations are increasingly taking place in international catalogs. However, the majority of the firms in this sector have no clear strategy towards attracting high-income tourists. The enterprises also give little attention to service diversification and customer segmentation.

Related and Supportive Industries: Tourism sector is connected with almost 49 different sectors (ranging from agriculture to construction). The more developments occur in related and supporting industries, the more competitive the tourism sector will become. Due to the fact that macroeconomic stability produced an average annual growth rate of 5.2\% between 2002 and 2011 (Turk Sat 2012), Turkey has been achieving a notable progress in the most of industries in terms of technological advances and quality of products and services which help the tourism sector progress. Educational institutions also support the sector adequately. There are a large number of tourism-related educational institutions (115 Tourism Vocational Schools, 50 Tourism Management departments at the universities). However, there are some obstacles which prevent taking full advantage of the sector's potential. Lack of coordination between related industries, weak integration between different alternative types of transportation such as airline, railways and roads, limited number of leisure alternatives (e.g. relatively small number of international festivals, concerts, Theme Parks such as Disneyland's), giving less attention to hygiene and quality standards of food and beverages served in restaurants, and inaccessibility of public and private transport companies due to language barriers can be considered as some of these obstacles.

\subsection{The Position of Turkey's Financial and Insurance Sector in the Context of both RCA and Porter's Diamond Model}

RCA findings: Even though Turkey has comparative advantages against France and Netherlands this appears to be opposite compared to all other European countries based on the export trade index. In addition to that, Turkey has no comparative advantage over any EU countries based on import and relative trade indices. When the change is scrutinized during the period of 2000-2010, Turkey's competitive status regarding export values has positively increased against France; however, the status based on the import has changed negatively in comparison with Belgium.

Factor Conditions: Banks play a dominant role in Turkish financial system. Therefore, factor conditions regarding bank system can be considered as the most important determinants of competitiveness of Turkish financial system. After a huge financial crisis in 2001, Turkey's financial system has deepened and relatively a good banking regulation system has been established. The banking sector has started to focus on core banking activities such as lending. Availability of a large and well-trained workforce and having a strong liquidity in banks are positive aspects of the Turkish banking system. Additionally, Turkey is one of the largest credit card markets in Europe, following the UK and Spain. However, the ratio of financial assets to GDP is still very low when compared with other developed countries. Similarly, the Turkish insurance market is significantly behind Europe in terms of market size. Therefore, there is low premium production per capita in insurance sub-sector. Another negative 
aspect of the system is that Turkish Individual Pension System is just based on voluntary participation.

Demand Conditions: Turkey's rapidly growing economy also lifted the level of per capita income and the rate of inflation has been gradually decreased. As a result, demand for housing and automobile loans have increased in recent years. Additionally, the weight of loans has increased significantly after 2007 and is expected to reach $58 \%$ in 2014 as a result of the expected increase in demand (ISPAT, 2010). However, Turkey is still high dependent on short term capital inflows. One of the main threats is high credit card loans and non-performing loans for Turkish banking system. Despite the decline in commercial loans, the rate of non-performing loans continues to increase. Deposits still remain the main funding source for banking industry. Additionally, the level of awareness of financial and insurance products among the people is low. Therefore, there is a low demand on insurance products for both life and non-life branches.

Firm Strategy and Rivalry: Turkey is the 13th most attractive destination for Foreign Direct Investment (FDI) in the world (A.T. Kearney, 2012). Accordingly, high FDI inflow has been realized into Turkish banking and insurance sector in recent years. Of the 48 banks that operate in Turkey, 16 are deposit-taking banks with more than 50 per cent foreign ownership (TBB, 2012). Main Turkish banks have been frequent users of international syndicated loans. Despite the fact that Turkish banks have an advantage of scale economies, Foreign-owned banks have much more market power than local ones. Also, the financial companies mostly focus on short term profitability (especially insurance companies). Moreover, it can be said that especially insurance companies have not been successful on increasing awareness of insurance.

Related and Supportive Industries: The main supportive and related industries of financial sector are automotive and construction as the growth of these industries leads to the growth of financial and insurance sector. It should also be noted that the technological infrastructure of financial institutions highly depends on foreign IT companies.

\subsection{The Position of Turkey's Communication and Computer-Information Sector in the Context of both RCA and Porter's Diamond Model}

RCA findings: The average values indicate that Turkey has no comparative advantage over any EU country based on export and relative trade indices. Nevertheless, based on the import figures Turkey has comparative advantages against all the European countries. As for the change between the years 2000 and 2010, Turkey has changed its position to being advantageous against Spain in both export and relative trade indices, but lost its advantageous position to France in import index.

Factor Conditions: Highly qualified human resources, very competent, young and dynamic computer engineers and software developers, are one of the most important positive aspects of Turkey's communication and computer-information sector. Developments including deregulation in Telecoms market, introducing new infrastructure and products such as $3 \mathrm{G}$, establishing new techno parks in many university campuses and favourable tax incentives and R\&D supports from government for the companies in this sector led new entrants to be in the market in recent years. National projects including broadband infrastructure within the military, computer labs in schools and internet connections to distant provinces and towns were implemented. 
However, Turkey still has lack of skilled and educated labour due to the fact that demand and production in this sector are increasing. There are also other negative aspects regarding factor conditions of this sector such as having low broadband penetration, high dependency on imports for the most of the inputs including telecommunications hardware, software and computer equipment, high software piracy rate, underdeveloped collaboration culture of R\&D and innovation (ISPAT, 2010a).

Demand Conditions: Due to the fact that Turkey has a very high rate of internet usage (Turkey is ranked \#1 in Europe for time spent and number of pages visited on the Internet) IT expenses have increased at a remarkable rate in the economy. There is also an increase in budget allocation by government for public IT investments. Government institutions are one of the biggest IT buyers. This can be considered both negative and positive in terms of developing a competitive structure in the sector. On one hand, due to the fact that most companies in other industries, particularly SMEs, see IT investments as a last resort, therefore these enterprises can benefit from the governmental IT expenses. On the other hand, high dependency on governmental demand also results underdevelopment of product and services diversity. Information and communication technologies in many enterprises are mostly limited to internet availability and accounting software. Moreover, the greatest obstacle to the development of sector is high usage of unlicensed software productions.

Firm Strategy and Rivalry: Even though the market is shared relatively by a small number of big companies, some of them successfully pursue a global multi-business strategy via partnerships, acquisitions, and investments as opposed to organic growth. Sellers are introducing new ways of shopping such as private sales, exclusive membership and improved technologies such as instant price and specification comparison. However, patent statistics show that domestic competition in technology products is not at the level of the 'Western' standards yet.

Related and Supportive Industries: Banking, media and entertainment, wholesale and retail trade sectors are main related and supportive industries, as they demand most of the production generated by the communication and computer-information sector. However, the capital market is not efficient enough to provide funding to start-ups and new companies.

\subsection{The Position of Turkey's Construction Sector in the Context of both RCA and Porter's Diamond Model}

RCA findings: Except Germany (for export index) and United Kingdom (for import index) Turkey has comparative advantage over almost all of the European countries based on all three indices. Over the years, the advantageous status of Turkey against Spain has increased (import), but the outlook appears to turn into negative in comparison with Germany (export).

Factor Conditions: Turkey is among the top countries who export construction services. The Turkish construction sector undertook around 6700 Project worth more than $\$ 230$ billion in 96 countries till 2012 (TCA, 2012). Turkey has a competent infrastructure in construction material industry, and satisfactory resources such as natural resources, wood products and iron which can be used in production. Additionally, due to the fact that construction is largely based on labor production techniques, Turkey has an advantage in this sector in terms of having a large and cheap 
work-force. However, the average level of education of people work in the sector is still low. This leads to a decrease in labour productivity. Construction sector in Turkey is the third lowest level of labour productivity among others. There are other unfavourable factors such as limited energy resources and low level of renewable energy production, which increase the costs and become an obstacle for the development of the sector. Turkey's construction sector does not display an institutionalized structure; thus, the abilities of representatives of the sector are far from European countries level in terms of planning and control.

Demand Conditions: Today, the players in the sector are operating in four continents and around 100 countries, using all the financial, managerial and technical instruments of international contracting standards (TCA, 2012). According to the leading international industry magazine "ENR - Engineering News Record" (2012), with 33 companies among the top 225 contracting companies, Turkey ranked second in the World after China in 2012. With regards to domestic demand, Turkey is highly dependent on the construction industry in fulfilling its need of infrastructural, residential, commercial, educational, and industrial type construction. Therefore, both quantity and quality of international and domestic demand support the development of the construction sector.

Firm Strategy and Rivalry: Turkey's construction sector is dominated by small and medium sized enterprises, and there is an intense competition among the firms in the sector. However, there is also a monopolistic structure in certain constructionrelated markets due to the fact that some companies have a wide and long experience in both domestic and international projects. Therefore, there are huge market share and profit differences among the firms. Additionally, since the entry barriers are low, the biggest customer is government, and demand is fluctuated in this sector; the level of competition is mainly based on financial advantages and politic power.

Related and Supportive Industries: Turkey is a major producer of basic construction materials such as cement, building steel, timber, bricks, PVC, polyethylene, glass, ceramic tiles and sanitary ware and is considered to be relatively strong and competitive in producing construction steel, cement, ceramic and glass products (Ministry of Economy, 2012). However, Turkey is highly dependent on import in terms of construction machines.

The results of the aforementioned explanations pertaining to the competitiveness of Turkey were summarized in Table 4 and Table 5.

Table 4 Complied summary of diamond variables of Turkey's service

\begin{tabular}{|l|l|l|l|l|}
\hline & $\begin{array}{l}\text { Factor } \\
\text { Conditions }\end{array}$ & $\begin{array}{l}\text { Demand } \\
\text { Conditions }\end{array}$ & $\begin{array}{l}\text { Strategy and } \\
\text { Rivalry }\end{array}$ & $\begin{array}{l}\text { Related and } \\
\text { Supportive } \\
\text { Industries }\end{array}$ \\
\hline Transportation & Moderate & Moderate & Moderate & Strong \\
\hline Tourism and & Strong & Moderate & Moderate & Moderate \\
\hline $\begin{array}{l}\text { Financial } \\
\text { Insurance }\end{array}$ & Weak & Moderate & Moderate \\
$\begin{array}{l}\text { Communication } \\
\text { Information }\end{array}$ & Weak & Weak & Moderate & Moderate \\
\hline Construction & Strong & Strong & Moderate & Moderate \\
\hline
\end{tabular}


Table 5 Compiled summary of the comparative advantage

\begin{tabular}{|c|c|c|c|c|c|c|c|}
\hline \multirow[t]{2}{*}{ Sectors/Indices } & \multicolumn{2}{|l|}{ RCA } & \multicolumn{2}{|l|}{ RMA } & \multicolumn{2}{|l|}{ RTA) } & \multirow{2}{*}{\begin{tabular}{|l} 
Prominent EU \\
Countries
\end{tabular}} \\
\hline & Pro(s) & Con(s) & $\operatorname{Pro}(\mathrm{s})$ & Con(s) & Pro(s) & Con(s) & \\
\hline $\begin{array}{l}\text { Transportation } \\
\text { (22\% of total } \\
\text { services export) }\end{array}$ & $\begin{array}{l}\text { UK, ITA } \\
\text { and ES }\end{array}$ & $\begin{array}{l}\text { DE, BE, FR, } \\
\text { and NL }\end{array}$ & & $\begin{array}{l}\text { All EU } \\
\text { countries }\end{array}$ & & $\begin{array}{l}\text { All EU } \\
\text { countries }\end{array}$ & $\begin{array}{l}\text { DE, BE, and } \\
\text { FR }\end{array}$ \\
\hline \begin{tabular}{|l|} 
Tourism $(63 \%$ of \\
total services \\
export $)$
\end{tabular} & $\begin{array}{l}\text { All EU } \\
\text { countries }\end{array}$ & & $\begin{array}{l}\text { Other EU } \\
\text { countries in } \\
\text { Travel } \\
\text { subsector }\end{array}$ & \begin{tabular}{|l} 
ES and NL \\
in Travel \\
subsector \\
All EU \\
countries in \\
Cultural- \\
Recreational \\
Activities \\
subsector
\end{tabular} & \begin{tabular}{|l} 
Other EU \\
countries in \\
Travel \\
subsector \\
Other EU \\
countries in \\
Cultural- \\
Recreational \\
Activities \\
subsector \\
\end{tabular} & $\begin{array}{l}\text { ES in travel } \\
\text { subsector } \\
\text { UK in } \\
\text { Cultural- } \\
\text { Recreational } \\
\text { Activities } \\
\text { subsector }\end{array}$ & $\begin{array}{l}\text { FR, ES, ITA, } \\
\text { and DE }\end{array}$ \\
\hline $\begin{array}{l}\text { Financial and } \\
\text { Insurance } \\
\text { (4\% of total } \\
\text { services export) }\end{array}$ & FR and NL & $\begin{array}{l}\text { Other EU } \\
\text { count. }\end{array}$ & & $\begin{array}{l}\text { All EU } \\
\text { countries }\end{array}$ & & $\begin{array}{l}\text { All EU } \\
\text { countries }\end{array}$ & $\begin{array}{l}\mathrm{UK}, \mathrm{DE} \text {, and } \\
\mathrm{BE}\end{array}$ \\
\hline $\begin{array}{l}\text { Comm. and } \\
\text { Computer- } \\
\text { Information } \\
(14 \% \text { of total } \\
\text { services export) }\end{array}$ & & $\begin{array}{l}\text { All EU } \\
\text { count. }\end{array}$ & $\begin{array}{l}\text { All EU } \\
\text { countries }\end{array}$ & & $\begin{array}{l}\text { Other EU } \\
\text { countries }\end{array}$ & $\begin{array}{l}\mathrm{DE}, \mathrm{UK} \text {, and } \\
\mathrm{BE}\end{array}$ & $\begin{array}{l}\text { UK, DE, FR, } \\
\text { and BE }\end{array}$ \\
\hline \begin{tabular}{|l} 
Construction \\
(3\% of total \\
services export) \\
\end{tabular} & $\begin{array}{l}\text { Other EU } \\
\text { countries }\end{array}$ & $\mathrm{DE}$ & $\begin{array}{l}\text { Other EU } \\
\text { countries }\end{array}$ & UK & $\begin{array}{l}\text { All EU } \\
\text { countries }\end{array}$ & & $\begin{array}{l}\text { DE, NL, and } \\
\text { FR }\end{array}$ \\
\hline
\end{tabular}

\section{Conclusion}

Existing body of literature on measuring the competiveness in services for developing countries, particularly for Turkey, has lack of comparative studies. In order to fill this gap in the literature to an extent, this study was conducted by focusing on competitiveness of the selected services in Turkey in comparison with the EU and the selected EU countries. The competiveness of these sectors were measured based on three comparative advantage indices. Import and export figures of selected countries in six service sectors were taken into consideration between the years 2000 and 2011. Also, the underlying reasons behind RCA analyses were investigated by performing some examination utilizing the Diamond model. When the results were analysed carefully the following discussions can be made.

First, even though Turkey has increased its export performance and relative competitiveness status in transportation sector for the last ten years, it might be hard to conclude that Turkey possess a very strong competitive advantage over selected European countries. Yet, developments including the strength of the country's effectiveness in the region, the growth in its manufacturing industries and accordingly in its foreign trade clearly indicate that Turkey's competiveness in transportation sector will grow incrementally and possess more comparative advantage over the coming years. Due to the transportation policy in recent years, Turkish government has invested in many projects in transportation sector. With the completion of these investments, Turkey will have become more effective and possess more comparative advantage in transportation sector in its region. 
Second, tourism sector appears to be one of the most important drivers behind Turkey's economic development in recent years. As it was mentioned before, both in travel and cultural-recreational subsectors, Turkey's revealed comparative advantages against all of the European countries were found to be greater than one. However, Turkey's tourism has not reached the desired level with regards to use of its potential. Although Turkey deserves to be at the top in the favored tourism destinations due to factor endowments such as rich historical, cultural and natural resources, improved touristic infrastructure and its tradition of hospitality, Yet, the main issue of Turkish tourism sector is that the summer vacations (sea-sun-sand tourism) has the biggest share of receipts, therefore it is necessary to take action plans related to the extension of tourism varieties including tableland tourism, cultural tourism and mountain tourism.

Third, Turkish financial and insurance sector has undergone significant changes due to the regulation and deregulation over the past decade. As a result of regulations and deregulations made by the Turkish Banking Regulation and Supervision Authority, the Turkish financial services sector grew in total by a compound annual growth rate (CAGR) of almost 20\% between 2004 and 2011. However, the comparative advantage of Turkish financial and insurance sector does not appear to be very good. One possible reason behind this could be the fact that Turkey is a latecomer in this sector in comparison with the rest of Europe. The main weakness of Turkish financial and insurance sector is Turkey's dependence on short-term capital inflows prevents aggressive reduction in interest rates. Also, low GDP per capita in this country is holding back the growth of the sector.

Fourth, as far as the communication and computer-information sector is concerned, although import figures of Turkey look promising but current competitiveness status based on the export and the net trade does not appear to be well. However, over the past decade, Turkey's telecommunication industry has been dramatically growing, driven by the market liberalization designed to enhance competition.

Fifth, in construction industry Turkey has a strong comparative advantage over the selected EU countries and EU overall. Turkish construction companies benefit from a low-cost labour advantage in some geographical markets. They also seek to become engineering-procurement-construction (EPC) contractors that have high technology and know-how as an alternative competitive advantage (Korkmaz and Messer, 2008). However, that even though with 33 companies among the top 225 contracting companies Turkey ranked second in the world after China in 2012, Turkish construction firms still have a low stake compared to EU countries in terms of market share in international markets.

In conclusion, construction, tourism and transportation sectors appear to be quite lucrative for Turkey which leads the country having a strong comparative advantage compared to the EU. However, the same inference seems not to be valid for financial and insurance and communication and computer-information sectors. Nevertheless, taking into account the recent developments that is triggering the economical and the political status of Turkey in a favorable way Turkey possesses great potential in the sectors at which they could be considered their early stage.

Although this study sheds a light on the competitiveness of certain Turkish service industries in comparison with selected European countries, it also has few limitations 
which could be considered as areas for future work. First, the sectors being chosen in this study could have been investigated in detail however, due to the availability problem of trade data at sub-sectorial level this could not been achieved. Therefore, as more detailed data becomes available a future work may repeat the analyses for different service sub-sectors. Also, further examination can also be performed using other comparative advantage indices.

Second, the determinants of the competitiveness of the sectors in the light of Diamond Model have been evaluated only for Turkey. The future studies can also carry out similar Diamond Model based assessments on identifying the determinants of the competitiveness for the selected EU countries.

\section{References}

Balassa, B. (1965). Trade liberalization and "revealed" comparative advantage' The Manchester School, 33, 99-123.

Bensidoun, I., Ünal, D. (2008), "Globalization in services: from measurement to analysis” OECD Statistics Working Papers, 2008/03, OECD Publishing.

Dgl., C. Holt Brügge, D. (2010). Competitive advantage of German renewable energy firms in Russia - an empirical study based on Porter's diamond, Journal for East European Management Studies, Vol. 15 No. 1, and pp. 34-58.

ENR. Engineering News Record (2012) "Top international contractors" Retrieved from http://enr.construction.com/toplists/Top-International-Contractors/001-100.asp

Eurostat (2008) European Union-Mediterranean Countries: Growing trade in services and investment. Economy and Finance Eurostat Statistics in Focus 106.

Fourier, J., Fintel, D. V. (2009). "World rankings of comparative advantage in service exports" Stellenbosch Economic Working Papers, 03, 1-41.

Francois, J., Pindyuk, O., Woerz, J, (2009). "Trends in international trade and FDI in services: a global database of services trade," IIDE Discussion Papers 20090802, Institute for International and Development Economics.

Hisanaga, M. (2007). "Comparative advantage structure of U.S. international services" Interfaces for Advanced Economic Analysis, Kyoto University, 1-21.

Hisanaga, M. (2008). "Revealed specialization: evidence on U.S. international services" Kyoto University, Institute of Economic Research.

Hoekman, B., Mateo, A. (2008). "Services trade and growth" World Bank, Policy Research Working Paper, 4461.

Hufbauer, G., Stephenson, S. (2007). "Services trade: past liberalization and future challenges." Journal of International Economic Law. 10(3), 605-630.

Igawa, K. (1997). "A note on international trade in services" Kokumin-Keizai Zasshi, $175,1--13$.

Ispat, A (2010). “Turkish tourism industry report” Republic of Turkey Prime Ministry Investment Support and Promotion Agency 
Retrieved from:

http://www.invest.gov.tr/enus/infocenter/publications/documents/tourism.industry .pdf

ISPAT, B (2010,). "Turkish financial service industry report", Republic of Turkey Prime Ministry Investment Support and Promotion Agency retrieved from: http://www.invest.gov.tr/enUS/infocenter/publications/Documents/FINANCE.IN DUSTRY.PDF

$\mathrm{Ju}$, Jiandong, Wei, Shang-Jin,(2011). When is quality of financial system a source of comparative advantage, Journal of International Economics, Volume, July 2011, 178-186

Kearney,A.T,(2012). FDI confidence index Retrieved from http://www.atkearney.com/gbpc/foreign-direct-investment-confidence-index

Korinek, J.,Sourdin, P.(2011). To what extent is high-quality logistics services trade facilitating? OECD Trade Policy Working Papers, No: 108, OECD Publishing.

Kuznar, A. (2007). International trade in services in developing countries - threats and opportunities are developing countries competitive? TSG 2007 Athens Ninth Annual Conference 13-15 September 2007. Athens

Langhammer,R.J (2007). Service trade liberalization as a handmaiden of competitiveness in manufacturing: An industrialized or developing country issue? Journal of World Trade, 41(5), 909-929.

Langhammer,R.J.(2004). "Revealed comparative advantages in service trade of the USA, EU, and Japan. What do they tell us?" Journal of World Investment Trade 6, 887--896

Maurizio,P.(2006). "The service paradox and endogenous economic growth" Structural Change and Economic Dynamics, 17: 99-115.

Ministry Of Economy, Republic Of Turkey (2012). "Building materials, Sectorial, Report".Retrieved from:

http://www.tcp.gov.tr/english/sectors/sectoringpdf/building_materials_2012.pdf

Ministry Of Industry and Trade (2010) “Turkish industrial strategy document” Retrieved from:

http://www.sanayi.gov.tr/Files/Documents/TurkiyeSanayiStratejisiIngilizce.pdf

Ministry Of Transport and Communication, (2011) “Country report” Retrieved from:http://www.comcec.org/UserFiles/File/ulastirma/\%C3\%9CLKE\%20RAPOR LARI/Turkey.pdf

Mohammadi, S., Yaghoubi, P. (2008) "Analysis of revealed comparative advantage in the e-service market" 2008 IEEE International Conference on System of Systems Engineering (Sose), 148-153.

Nielson, J., Taglioni, D. (2004). "Services trade liberalization: identifying opportunities and gains." OECD Trade Policy Working Papers, No: 1, OECD Publishing.

Nordas, H. K. (2008). "The impact of services trade liberalization on trade in nonagricultural products," OECD Trade Policy Working Papers, No: 81, OECD Publishing. 
OECD,(1990). "Trade in information, computer and communication services" No: 21, OECD Digital Economy Papers, No: 2, OECD Publishing.

Oz, O. (2002) “Assessing Porter's framework for national advantage: The case of Turkey" Journal of Business Research. 55: 509-515.

Pettigrew, A.M. (1990). "Longitudinal field research on change: theory and practice." Organization Science, 1, 267-292.

Porter, M. E. (1980) "Competitive strategy: techniques for analyzing industries and competitors" Free Press.

Porter, M.E. (1990). "The Competitive advantage of nations" The Macmillan Press Ltd., London and Basingstoke.

Ricardo, D. (1996). 'Principles of political economy and taxation”, Prometheus Books'

Seyoum, B.(2007). "Revealed comparative advantage and competitiveness in services" Journal of Economic Studies, 34, 376 - 388.

Sledge, S. (2005). "Does Porter's diamond hold in the global automotive industry" Advances in Competitiveness Research, Vol. 13 No. 1, pp. 22-32.

TBB, Türkiye Bankalar Birliği, (2012), “Türkiye'de bankacılık sektörü 20072012".Retrievedfrom:http://www.tbb.org.tr/Dosyalar/Arastirma_veRaporlar/Turki ye'de_Bankacilik_Sektoru_2007-2012_Mart.pdf

TCA, Turkish Contractor Association, (2012). Turkish contracting in the international market' Sectorial Report". Retrieved from http://www.tmb.org.tr/genel.php?ID=2

TURKSTAT, Turkish Statistical Institute, (2012). "Statistical Database" 


\begin{tabular}{|l|l|}
\hline Appendix: Acronyms and Abbreviations \\
\hline BPM & Balance of Payments Methods \\
\hline CAGR & Compound Annual Growth Rate \\
\hline EBOPS & Extended Balance of Payments \\
\hline ENR & Engineering News Record \\
\hline EPC & Engineering-procurement-construction \\
\hline EU & European Union \\
\hline FDI & Foreign Direct Investment \\
\hline GDP & Gross Domestic Product \\
\hline IATA & International Air Transport Association \\
\hline IMF & International Monetary Fund \\
\hline ISPAT & Prime Ministry Investment Support and Promotion Agency \\
\hline MPC & Mediterranean Partner Countries \\
\hline OECD & Organization for Economic Co-operation and Development \\
\hline RCA & Revealed Comparative Advantage \\
\hline RMA & Relative Import Advantage \\
\hline RTA & Relative Trade Advantage \\
\hline SME & Small and Medium-sized Enterprise \\
\hline TBB & Türkiye Bankalar Birliği (The Banks Associations of Turkey) \\
\hline TCA & Turkish Contractor Association \\
\hline WTO & World Trade Organization \\
\hline
\end{tabular}

